\title{
FORMULASI SOSIS DARI KERANG HIJAU DAN TEPUNG TEMPE DENGAN VARIASI KONSENTRASI AIR DAN AGAR-ALGINAT
}

\section{Formulation of Sausage from Asian Green Mussel and Tempeh Flour with Various Concentration of Water and Agar-Alginate}

\author{
Anugerah Dany Priyanto*, Sri Djajati \\ Program Studi Teknologi Pangan, Fakultas Teknik,Universitas Pembangunan \\ Nasional "Veteran" Jawa Timur \\ Jl. Rungkut Madya, Gunung Anyar, Surabaya, Jawa Timur 60294 \\ *Penulis Korespondensi, Email: anugerahdany.tp@upnjatim.ac.id
}

\begin{abstract}
ABSTRAK
Sosis merupakan produk olahan dengan bahan baku utama sumber tinggi protein yang salah satunya yaitu hasil perikanan. Tujuan dari penelitian ini yaitu memperbaiki sifat sensoris dan sifat fisik dari sosis yang terbuat dari kerang hijau dengan menambahkan tepung tempe dengan studi penambahan konsentrasi air yang bervariasi serta perbedaan konsentrasi hidrokoloid khususnya agar-alginat. Penelitian tahap pertama yaitu penentuan proporsi kerang hijau dan tepung tempe. Perlakuan terbaik dari tahap pertama dilanjutkan pada tahap kedua yaitu terfokus pada penambahan konsentrasi air dan konsentrasi agar-alginat. Rancangan penelitian yang digunakan pada tahap pertama dan kedua adalah Rancangan Acak Lengkap (RAL) dengan pengulangan sebanyak tiga kali. Hasil menunjukkan bahwa perlakuan terbaik diperolah pada proporsi kerang hijau dan tepung tempe sebesar $50 \%: 50 \%$ dengan penambahan konsentrasi air $60 \%$ serta penggunaan agar-alginat sebesar $2 \%$ memiliki kadar air $62.72 \pm 2,92 \%$, tekstur $0.28 \pm 0.01 \mathrm{~mm} / \mathrm{g} . \mathrm{s}$, WHC $19.07 \pm 0.58 \%$, dan stabilitas emulsi $92.54 \pm 0.72 \%$.
\end{abstract}

Kata kunci: Hidrokoloid, Kerang Hijau, Sosis, Tempe

\section{ABSTRACT}

Sausages are products with main ingredients as high-protein sources, which is fishery products. Aims of this study were improving sensory and physical properties of sausages made from Asian green mussels by adding tempeh flour with addition of various concentrations of water and hydrocolloids, particulary agar-alginate. First stage of this study was determining proportion of Asian green mussels and tempeh flour. Best treatment from first stage was continued to second stage, which is focused on increasing concentrations of water and agar-alginate. Research design used in first and second stages was a Completely Randomized Design (CRD) with triplicate measurements. Results showed that best treatment was obtained in proportion of Asian green mussels and tempeh flour by 50\%: $50 \%$ with addition of $60 \%$ water concentration with using agar-alginate by $2 \%$ has moisture content of $62.72 \pm 2.92 \%$, texture $0.28 \pm 0.01 \mathrm{~mm} / \mathrm{g} . \mathrm{s}, \mathrm{WHC} 19.07 \pm 0.58 \%$, and emulsion stability 92.54 $\pm 0.72 \%$.

Keywords: Asian Green Mussels, Hydrocolloid, Sausage, Tempeh 


\section{PENDAHULUAN}

Kerang hijau merupakan produk hasil perairan yang masih jarang diolah menjadi olahan produk pangan. Hasil produksi kekerangan telah dicapai sejumlah $50 \%$ pada 6 bulan pertama dari total 233,700 ton yang ditargetkan pada tahun 2015. Hasil tersebut diperkirakan akan terus meningkat sebesar 32.60\% per tahun hingga tahun 2019 (Kementerian Kelautan dan Perikanan, 2015). Kemunduran mutu pada produk segar akan terjadi seiring berjalannya waktu. Oleh karena itu, penanganan secara tepat dapat dilakukan sebagai upaya mempertahankan mutu. Salah satu bentuk pengolahan pangan yang dapat dilakukan yaitu dengan mengembangkannya menjadi sosis. Hal tersebut disebabkan kerang hijau memiliki kadar protein yang cukup baik, asam lemak esensial yang memadai serta vitamin dan mineral yang cukup lengkap (Chakraborty et al., 2016).

Sosis merupakan produk olahan pangan dengan bahan dasar protein hewani yang dicampur dengan beberapa rempah-rempah dan garam yang mengalami pencetakan dan pemasakan (Abdolghafour and Saghir, 2014). Akan tetapi, melihat penampakan dari warna kerang yang cukup gelap perlu adanya upaya untuk memperbaiki karakteristik tersebut. Oleh karena itu, perlu adanya bahan tambahan yang digunakan untuk memperbaiki warna yang dihasilkan ketika diolah menjadi sosis. Penambahan bahan yang berwarna cerah serta memiliki kadar protein yang cukup tinggi diharapkan dapat memperbaiki sifat sensoris khususnya warna yang salah satunya yaitu tempe. Di sisi lain, tempe mengandung peptida-peptida dan asam amino esensial yang baik digunakan oleh tubuh.

Selain penampakan warna, perlu juga adanya perbaikan tekstur dikarenakan sifat protein produk hasil perikanan kurang baik dalam pembentukan tekstur. Tekstur dan konsistensi suatu bahan sangat berpengaruh terhadap karakteristik organoleptik suatu produk pangan. Penambahan konsentrasi air pada komposisi sosis memiliki pengaruh yang nyata terhadap sifat sensori yang dihasilkan (Mohan, 2014; Chin et al., 2004). Selain itu, komponen hidrokoloid juga perlu ditambahkan untuk memperbaiki tekstur sosis yang diinginkan. Alginat merupakan salah satu jenis yang baik dalam pembentukan emulsi sosis (Beriain et al., 2011). Menurut Andrès et al. (2006) bahwa penggunaan hidrokoloid berupa agar dapat mengurangi kekerasan pada tekstur sosis. Oleh karena itu, perlunya ada penelitian lebih lanjut mengenai pengaruh penambahan konsentrasi air serta agar dan alginat untuk menghasilkan tekstur yang baik pada sosis.

Penelitian mengenai komoditas hasil perairan sudah banyak dilakukan, seperti sosis ikan cakalang (Sidu dkk., 2018), sosis ikan gabus (lqbal dkk., 2015), sosis ikan kembung (Nalendrya dkk., 2016), dan sosis ikan lele (Nisa dan Wardani, 2016). Hingga sampai saat ini, belum pernah dilakukan mengenai penelitian kerang hijau yang digunakan sebagai bahan baku utama sosis. Penelitian ini akan terfokus pada penentuan proporsi kerang hijau dan tempe untuk menentukan penampakan sosis yang baik serta menentukan penambahan konsentrasi air serta agar dan alginat yang menghasilkan tekstur sosis yang baik. Harapannya dengan adanya penelitian ini mampu menjadi solusi untuk meningkatkan nilai tambah dari kerang hijau serta menghasilkan sosis dengan karakteristik terbaik.

\section{BAHAN DAN METODE}

\section{Bahan}

Bahan yang digunakan dalam pembuatan sosis dan uji organoleptik adalah kerang hijau, tempe, tapioka, agar, alginat, putih telur, minyak goreng, bawang putih, bawang merah, merica, pala, jahe, gula, garam, dan kopi. Beberapa bahan untuk analisis fisik yaitu alkohol, akuades dan kertas saring. 
Alat

Alat yang digunakan dalam membuat produk ini adalah pisau, talenan, baskom, toples, ayakan, pengering cabinet, penghancur daging, pencetak sosis, tali pengikat, gelas ukur, piring, termometer, sendok, plastik, spatula, kompor, panci, dan timbangan. Beberapa peralatan yang digunakan untuk analisis antara lain timbangan analitik, gelas ukur, erlenmeyer, beaker glass, tabung reaksi, pemanas, oven, waterbath, labu ukur, corong, texture analyzer, pipet, lembar penilaian organoleptik, bilik pencicip, lembar penilaian organoleptic dan panelis non standar.

\section{Metode}

Penelitian dilakukan sebanyak 2 tahap. Tahap pertama yaitu penentuan proporsi kerang hijau dan tepung tempe. Pada tahap pertama akan diambil perlakuan terbaik yang akan dilanjutkan pada tahap kedua yaitu penambahan konsentrasi air dan konsentrasi agar-alginat. Rancangan penelitian yang digunakan pada tahap pertama adalah Rancangan Acak Lengkap (RAL) yang tersusun atas 1 faktor, dimana faktor tersebut terdiri dari 9 level dengan 3 kali ulangan, sehingga didapatkan 27 satuan percobaan. Faktor pada tahap pertama proporsi kerang hijau dan tepung tempe yaitu :

T1 : 10\%:90\% (b/b)

T2 : $20 \%: 80 \%(b / b)$

T3 : $30 \%: 70 \%(b / b)$

T4 : $40 \%: 60 \%(b / b)$

T5 : $50 \%: 50 \%(\mathrm{~b} / \mathrm{b})$

T6 : $: 60 \%: 40 \%(\mathrm{~b} / \mathrm{b})$

T7 : :70\%:30\% (b/b)

T8 : : 80\%:20\% (b/b)

T9 : $90 \%: 10 \%(b / b)$.

Rancangan penelitian yang digunakan pada tahap kedua adalah Rancangan Acak Lengkap (RAL) yang tersusun atas 2 faktor, dimana faktor tersebut terdiri dari 3 level sehingga didapatkan 9 kombinasi perlakuan. Semua perlakuan tersebut dilakukan 3 kali pengulangan, sehingga didapatkan 27 satuan percobaan. Faktor satu adalah penambahan konsentrasi air pada adonan sosis, A1 air 50\% (v/b), A2 air 60\% (v/b), A3 air 70\% dan faktor dua yaitu konsentrasi penambahan agar-alginat pada adonan sosis, B1 agar-alginat 1\% (b/b), B2 agar-alginat 2\%, B3 agar-alginat $3 \%$.

\section{Tahapan Penelitian dan Prosedur Analisis}

\section{Tahap Penentuan Proporsi Kerang Hijau dan Tepung Tempe}

Tahap ini dilakukan dengan mengamati sifat organoleptik melalui pengujian organoleptik dari sosis yang dihasilkan dengan berbagai macam proporsi kerang hijau dan tepung tempe. Sifat organoleptik diamati pada produk sosis mentah dan sosis matang (telah mengalami penggorengan). Parameter yang diamati pada sosis mentah yaitu warna, tekstur dan aroma. Pada sosis matang beberapa parameter yang diamati yakni rasa, warna, tekstur dan aroma.

Kerang hijau segar dikupas dan dipisahkan dari cangkangnya. Kerang hijau segar tanpa cangkang dicuci dengan air mengalir, direbus, ditimbang, ditiriskan dan dicatat massanya. Kerang hijau yang sudah direbus dihancurkan dengan penggiling daging hingga halus. Pembuatan tepung tempe dilakukan dengan pengeringan selama 6 jam dengan suhu $55 \pm 5{ }^{\circ} \mathrm{C}$ dengan pengering kabinet dan tepung tempe yang digunakan hanya tepung tempe yang lolos ukuran 80 mesh. Kerang hijau yang sudah dihancurkan hingga halus dan tepung tempe dicampur dengan proporsi yang telah ditentukan sesuai dengan perlakuan. Bahan tambahan seperti tapioka $20 \%$, putih telur $1 \%$ dan minyak goreng $15 \%$ serta bumbu seperti bawang putih $3.5 \%$, bawang merah $2 \%$, merica $0.5 \%$, pala $0.5 \%$, jahe $0.5 \%$, gula $2 \%$, dan garam $2 \%$ ditambahkan pada adonan yang akan dibuat sosis dengan ukuran penambahan yang telah dihitung. Pencampur adonan dilakukan 
hingga homogen. Setelah homogen, dimasukkan dalam alat pencetak sosis yang sudah terpasang selongsong plastik. Pencetakan dilakukan sesuai dengan ukuran yang telah ditentukan. Setelah dilakukan pencetakan, dilakukan pengukusan dengan suhu $95 \pm 5^{\circ} \mathrm{C}$ selama 45 menit hingga matang. Pendinginan dilakukan dengan tujuan untuk memberikan tekstur yang kompak setelah dilakukan pengukusan.

\section{Tahap Penentuan Penambahan Konsentrasi Air dan Agar-Alginat}

Pada tahap ini perlakuan terbaik dari tahap pertama akan dilakukan formulasi sosis dengan penambahan berbagai macam konsentrasi air serta kombinasi antara agar dan alginat. Konsentrasi agar-alginat yang ditambahkan sebesar $1 \%$, 2\%, dan $3 \%$ artinya pembagian kedua bahan tersebut sebanyak 50\%:50\%. Apabila penambahan sebanyak 1\%, maka konsentrasi agar sebesar $0.5 \%$ dan alginat $0.5 \%$ begitu juga dengan konsentrasi yang lain. Pada tahapan ini akan didapatkan satu formulasi terbaik dari variabel penelitian yang telah ditentukan. Sosis kerang hijau yang dihasilkan dari percobaan dipisahkan bagian sosis kerang hijau dan selongsong plastiknya kemudian bagian sosis kerang hijau dianalisis dengan beberapa macam parameter kadar air, tekstur, water holding capacity (WHC), dan kestabilan emulsi.

\section{HASIL DAN PEMBAHASAN}

\section{Karakteristik Organoleptik Sosis dengan Proporsi Kerang Hijau dan Tepung Tempe}

Uji organoleptik atau yang dikenal dengan uji inderawi merupakan penilaian mutu pangan menggunakan indra manusia. Uji hedonik merupakan salah satu jenis uji organoleptik yang digunakan pada peneltian ini. Uji hedonik digunakan untuk menentukan penerimaan (acceptable test) terhadap suatu produk pangan berdasarkan tingkat kesukaannya. Evaluasi ini dilakukan pada panelis sebanyak 35 orang. Skala tingkat kesukaan yang digunakan pada penelitian ini yaitu 1-5 (sangat tidak suka-sangat suka).

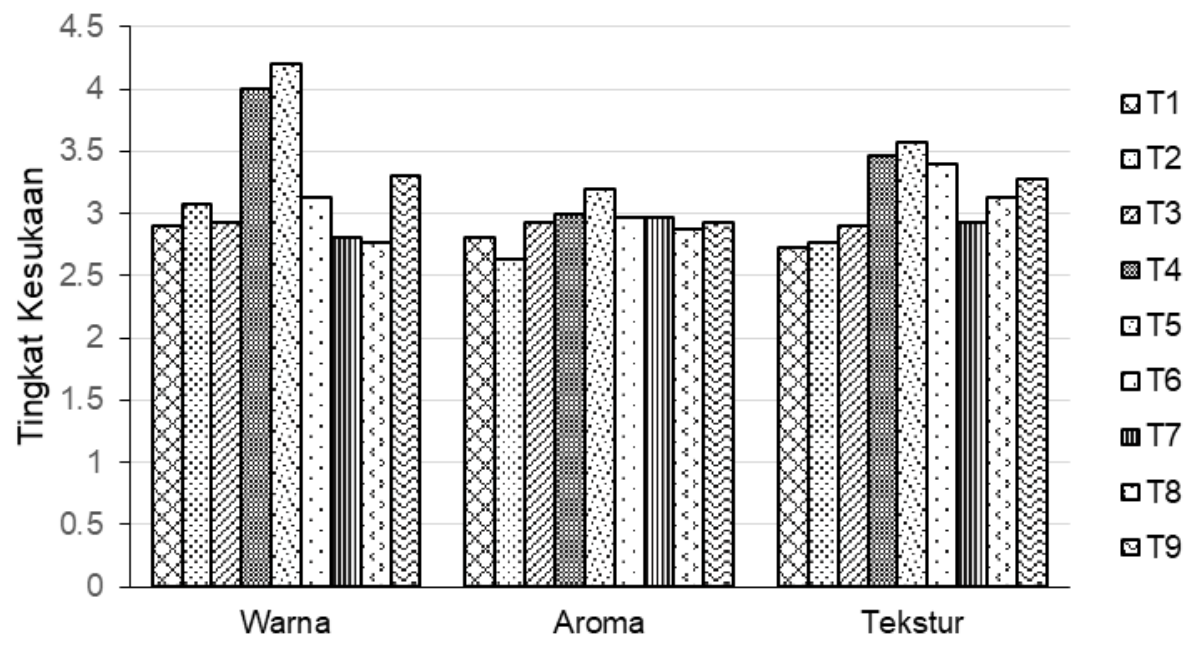

Gambar 1. Grafik hasil uji organoleptik sosis mentah dengan variasi perbedaan proporsi kerang hijau dan tepung tempe

Uji organoleptik pada penelitian ini digunakan pada sosis dengan 2 kondisi, yakni mentah dan matang. Mentah berarti sosis yang sudah mengalami pengukusan, tetapi belum mengalami penggorengan. Produk sosis matang merupakan sosis yang telah mengalami penggorengan yang siap untuk dikonsumsi. Pengujian organoleptik tersebut dilakukan untuk mengetahui 
keobjektifan dalam kesiapan saat berada di pasaran dikarenakan produk ini dijual dalam bentuk frozen food. Oleh karena itu, dilakukan pengujian produk mentah yang diasumsikan sebagai produk yang berada pada display penjualan dan sosis matang dianalogikan sebagai produk ready to eat.

Pada Gambar 1 menunjukkan bahwa sosis mentah dengan 9 macam perbedaan proporsi memiliki penilaian yang variatif yang dihasilkan dari assessment panelis pada tingkat kesukaan warna, aroma, dan tekstur. Tidak dilakukan evaluasi rasa pada sosis mentah, walaupun pada sosis ini juga sudah dilakukan proses thermal yang artinya tidak berbahaya dan dapat dikonsumsi, akan tetapi preferensi konsumen di Indonesia sosis yang dikonsumsi disajikan melalui proses penggorengan. Hasil evaluasi menunjukkan bahwa tingkat kesukaan paling tinggi pada uji warna, aroma, dan tekstur diperoleh pada produk sosis mentah dengan kode T5 yang artinya proporsi antara kerang hijau dan tepung tempe sebesar $50 \%: 50 \%$ (b/b) memiliki karakteristik yang paling disukai daripada proporsi yang lainnya.

Perlakuan proporsi antara kerang hijau dan tepung tempe 50\%:50\% (b/b) menjadi yang paling tinggi kesukaannya diduga karena perbandingan berat antara kerang hijau dan tempe sebanding, sehingga baik warna, aroma, dan tekstur tidak mencirikan salah satu dari komposisi. Kerang hijau memiliki karakteristik yang cenderung gelap dan lembek, sedangkan tepung tempe memiliki warna yang cerah dan tekstur membentuk adonan yang kering. Kombinasi kedua bahan yang sebanding akan membentuk warna yang tepat, aroma yang tidak terlalu spesifik pada salah satunya serta tekstur yang kompak yang artinya tidak lembek dan tidak kering.

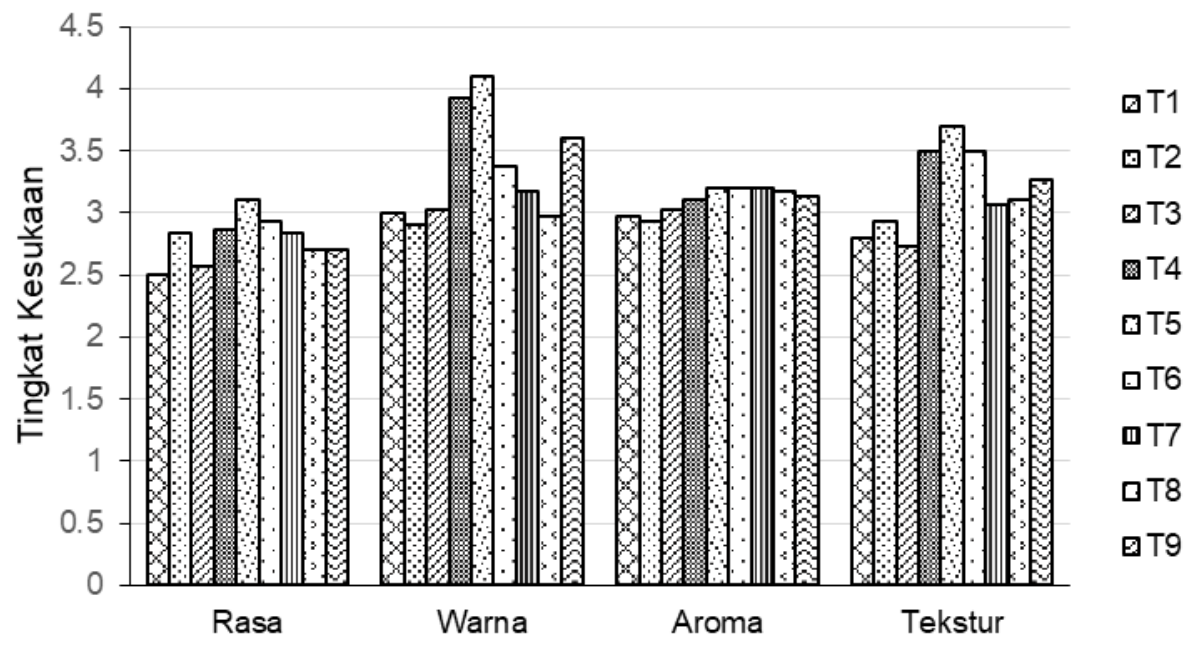

Gambar 2. Grafik hasil uji organoleptik sosis matang dengan variasi perbedaan proporsi kerang hijau dan tepung tempe

Pada Gambar 2 menunjukkan bahwa hasil uji organoleptik untuk parameter rasa, warna, aroma dan tekstur pada sosis yang telah digoreng untuk perlakuan paling disukai yaitu pada kode T5. Baik pada sosis mentah dan matang pada proporsi antara kerang hijau dan tepung tempe dengan perbandingan 50\%:50\% (b/b) menghasilkan karakteristik organoleptik paling baik. Proporsi yang sebanding diduga menjadikan karakteristiknya paling disukai. Seperti pada parameter aroma dengan proporsi yang sebanding, maka aroma amis dari kerang hijau maupun langu dari tempe akan membuat aroma menjadi lebih samar dari karakteristik keduanya, sehingga tingkat preferensinya akan lebih dapat diterima dibandingkan dengan yang lainnya. 


\section{Karakteristik Warna Sosis dengan Proporsi Kerang Hijau dan Tepung Tempe}

Warna adalah salah satu aspek yang menjadi parameter penerimaan produk makanan. Apabila penampakan warna terlihat menarik, maka akan meningkatkan kecenderungan konsumen untuk mengkonsumsinya. Pada nilai a menunjukkan derajat kemerahan suatu produk, yakni skala yang digunakan - 80 sampai 100 dengan semakin kecilnya nilai menunjukkan semakin hijau, sedangkan semakin besar nilainya menunjukkan semakin merah. Nilai $b^{*}$ memiliki skala 70 hingga 70, dimana semakin besar nilanya menunjukkan semakin kuning dan semakin rendah nilainya menunjukkan warna biru (Leon et al., 2006).

Data penelitian dapat dilihat pada Tabel 1, 2, dan 3 bahwa proporsi antara kerang hijau dan tepung tempe yang berbeda menghasilkan nilai warna yang berbeda-beda, baik kecerahan $\left(L^{\prime}\right)$, kemerahan $\left(a^{\prime}\right)$, dan kekuningan $\left(b^{\prime}\right)$. Hasil uji statistik menunjukkan bahwa perbedaan proporsi pada sosis berpengaruh nyata terhadap nilai $L^{*}, a^{*}$, dan $b^{*}$. Pada sosis matang untuk nilai $L^{*}$ secara umum lebih rendah daripada sosis mentah. Hal tersebut diakibatkan karena adanya proses penggorengan sehingga warna yang dihasilkan lebih gelap. Suhu tinggi akan menyebabkan beberapa reaksi-reaksi kimia seperti denaturasi, perubahan kelarutan, perubahan warna, derivatisasi residu asam amino, dan pembentukan beberapa senyawa yang menyebabkan sifat sensori menjadi berubah (Sundari dkk., 2015). Proporsi tepung tempe yang lebih banyak akan mengakibatkan tingkat kecerahan semakin meningkat.

Tabel 1. Rerata Nilai Kecerahan $\left(L^{*}\right)$ pada Permukaan Sosis

\begin{tabular}{cccc}
\hline \multirow{2}{*}{ Formulasi } & $\begin{array}{c}\text { Proporsi }(\%) \\
\text { Kerang Hijau : Tepung Tempe }\end{array}$ & \multicolumn{2}{c}{ Kecerahan $\left(L^{*}\right)$} \\
\cline { 2 - 4 } & $10: 90$ & $56.33^{\mathrm{bc}} \pm 5.17$ & $25.27^{\mathrm{bc}} \pm 1.65$ \\
T1 & $20: 80$ & $65.47^{\mathrm{a}} \pm 4.65$ & $22.70^{\mathrm{abc}} \pm 6.60$ \\
T2 & $30: 70$ & $45.43^{\mathrm{d}} \pm 5.35$ & $26.63^{\mathrm{c}} \pm 6.94$ \\
T3 & $40: 60$ & $53.97^{\mathrm{bc}} \pm 6.82$ & $26.60^{\mathrm{c}} \pm 10.50$ \\
T4 & $50: 50$ & $54.57^{\mathrm{bc}} \pm 8.18$ & $26.70^{\mathrm{c}} \pm 7.55$ \\
T5 & $60: 40$ & $60.13^{\mathrm{ab}} \pm 6.49$ & $18.80^{\mathrm{abc}} \pm 5.81$ \\
T6 & $70: 30$ & $34.30^{\mathrm{f}} \pm 8.69$ & $14.80^{\mathrm{ab}} \pm 2.77$ \\
T7 & $80: 20$ & $35.87^{\mathrm{f}} \pm 10.96$ & $13.50^{\mathrm{a}} \pm 3.48$ \\
T8 & $90: 10$ & $43.13^{\mathrm{e}} \pm 1.56$ & $17.27^{\mathrm{abc}} \pm 4.27$ \\
T9 & &
\end{tabular}

Keterangan : Data yang diikuti tanda huruf kecil yang berbeda pada kolom yang sama menunjukkan perbedaan yang nyata $(P<0,05)$

Tabel 2. Rerata Nilai Kemerahan $\left(a^{*}\right)$ pada Permukaan Sosis

\begin{tabular}{|c|c|c|c|}
\hline \multirow{2}{*}{ Formulasi } & \multirow{2}{*}{$\begin{array}{c}\text { Proporsi (\%) } \\
\text { Kerang Hijau : Tepung Tempe }\end{array}$} & \multicolumn{2}{|c|}{ Kemerahan $\left(a^{\prime}\right)$} \\
\hline & & Sosis mentah & Sosis matang \\
\hline T1 & $10: 90$ & $-3.90 \pm 0.46$ & $10.43^{b} \pm 1.27$ \\
\hline T2 & $20: 80$ & $-1.00^{b c} \pm 0.66$ & $11.87^{b c} \pm 1.00$ \\
\hline T3 & $30: 70$ & $-1.57^{\mathrm{ab}} \pm 0.42$ & $15.47^{c} \pm 4.61$ \\
\hline T4 & $40: 60$ & $4.47^{\mathrm{d}} \pm 1.82$ & $11.67^{\mathrm{bc}} \pm 3.77$ \\
\hline T5 & $50: 50$ & $4.20^{d} \pm 2.11$ & $16.07^{\circ} \pm 3.80$ \\
\hline T6 & $60: 40$ & $-1.13^{\mathrm{abc}} \pm 0.15$ & $3.93^{\mathrm{a}} \pm 1.92$ \\
\hline $\mathrm{T} 7$ & $70: 30$ & $-2.77^{\mathrm{ab}} \pm 1.50$ & $1.17^{a} \pm 0.59$ \\
\hline T8 & $80: 20$ & $-0.77^{b c} \pm 3.12$ & $0.63^{\mathrm{a}} \pm 0.51$ \\
\hline T9 & $90: 10$ & $1.37^{c} \pm 0.68$ & $2.90^{\mathrm{a}} \pm 0.95$ \\
\hline
\end{tabular}

Keterangan : Data yang diikuti tanda huruf kecil yang berbeda pada kolom yang sama menunjukkan perbedaan yang nyata $(P<0,05)$ 
Tabel 3. Rerata Nilai Kekuningan $\left(b^{*}\right)$ pada Permukaan Sosis

\begin{tabular}{cccc}
\hline \multirow{2}{*}{ Formulasi } & $\begin{array}{c}\text { Proporsi }(\%) \\
\text { Kerang Hijau : Tepung Tempe }\end{array}$ & \multicolumn{2}{c}{ Kekuningan $\left(\boldsymbol{b}^{\boldsymbol{}}\right)$} \\
\cline { 2 - 4 } & $10: 90$ & $14.47^{\mathrm{c}} \pm 1.47$ & $9.93^{\mathrm{bc}} \pm 2.68$ \\
T1 & $20: 80$ & $3.97^{\mathrm{a}} \pm 1.80$ & $10.70^{\mathrm{bc}} \pm 6.72$ \\
T2 & $30: 70$ & $6.77^{\mathrm{a}} \pm 1.01$ & $11.07^{\mathrm{bc}} \pm 6.59$ \\
T3 & $40: 60$ & $30.70^{\mathrm{e}} \pm 0.20$ & $11.83^{\mathrm{bc}} \pm 6.11$ \\
T4 & $50: 50$ & $32.80^{\mathrm{c}} \pm 1.68$ & $12.63^{\mathrm{c}} \pm 5.56$ \\
T5 & $60: 40$ & $4.40^{\mathrm{a}} \pm 1.75$ & $4.53^{\mathrm{a}} \pm 3.48$ \\
T6 & $70: 30$ & $12.10^{\mathrm{bc}} \pm 5.80$ & $0.63^{\mathrm{a}} \pm 1.42$ \\
T7 & $80: 20$ & $8.47^{\mathrm{ab}} \pm 2.50$ & $0.20^{\mathrm{a}} \pm 1.40$ \\
T8 & $90: 10$ & $22.30^{\mathrm{d}} \pm 1.93$ & $3.10^{\mathrm{ab}} \pm 5.80$ \\
T9 & & &
\end{tabular}

Keterangan : Data yang diikuti tanda huruf kecil yang berbeda pada kolom yang sama menunjukkan perbedaan yang nyata $(P<0,05)$

Nilai kemerahan pada sosis matang bernilai positif, sedangkan pada sosis mentah memiliki nilai negatif. Hal tersebut menunjukkan bahwa sosis matang yang telah mengalami penggorengan berwarna lebih merah dibandingkan dengan sosis mentah. Sosis ini terbuat dari kerang hijau, oleh karena itu nilai negatif pada kerang mentah diakibatkan karena bahan bakunya memiliki warna kehijauan. Perlakuan penggorengan menyebabkan adanya reaksi Maillard yang terbentuk akibat adanya reaksi antara gula reduksi dengan gugus amin bebas. Gula reduksi pada produk ini bersumber dari bahan-bahan karbohidrat seperti tapioka dan gula, sedangkan gugus amin bebas berasal dari bahan bakunya yang mengandung protein seperti kerang hijau dan tepung tempe serta bahan tambahan seperti putih telur. Oleh karena itu, hal ini sejalan dengan nilai kekuningan dimana sosis sebelum dilakukan penggorengan cenderung memiliki warna lebih kuning dikarenakan bahan baku dari kerang hijau kearah hijau kuning kecoklatan. Pada produk sosis matang nilai $b^{*}$ lebih kecil akibat penggorengan mengakibatkan warna berubah menjadi gelap, sehingga intensitas warna kuningnya akan berubah.

\section{Karakteristik Fisik Sosis dengan Penambahan Agar-Alginat}

Hasil dari penelitian tahap pertama mengenai penentuan proporsi kerang hijau dan tepung tempe didapatkan satu perlakuan terbaik dengan pengkajian uji sensoris terdapat pada formulasi 50\% : 50\% yang dapat dilihat pada Gambar 1 pada karakteristik warna, aroma dan tekstur serta Gambar 2 pada karakteristik rasa, warna, aroma dan tekstur Oleh karena itu, penelitian selanjutnya dengan formulasi dasar yang mempertimbangkan penampakannya tersebut lebih difokuskan untuk memperbaiki sifat fisiknya. Perbaikan sifat fisik dilakukan dengan menambahkan agar-alginat dengan konsentrasi yang berbeda-beda. Parameter yang diamati meliputi kadar air, water holding capacity (WHC), stabilitas emulsi, dan tekstur.

\section{a. Kadar Air}

Gambar 3 menunjukkan bahwa kombinasi antara penambahan air dan agar-alginat akan meningkatkan kadar air dari sosis. Hasil penelitian menunjukkan bahwa semakin tinggi penambahan konsentrasi air pada adonan sosis, maka semakin tinggi kadar air sosis yang dihasilkan. Begitu juga dengan meningkatnya kadar air juga disebabkan karena semakin tinggi konsentrasi penambahan hidrokoloid berupa agar-alginat. Kadar air sosis berkisar antara 51.00 $\pm 0.99 \%$ hingga $70.73 \pm 2.33 \%$. Hasil analisis ragam menginterpretasikan mengenai pengaruh variasi konsentrasi air dan agar-alginat memiliki pengaruh yang nyata terhadap kadar air sosis pada taraf uji $5 \%$. 


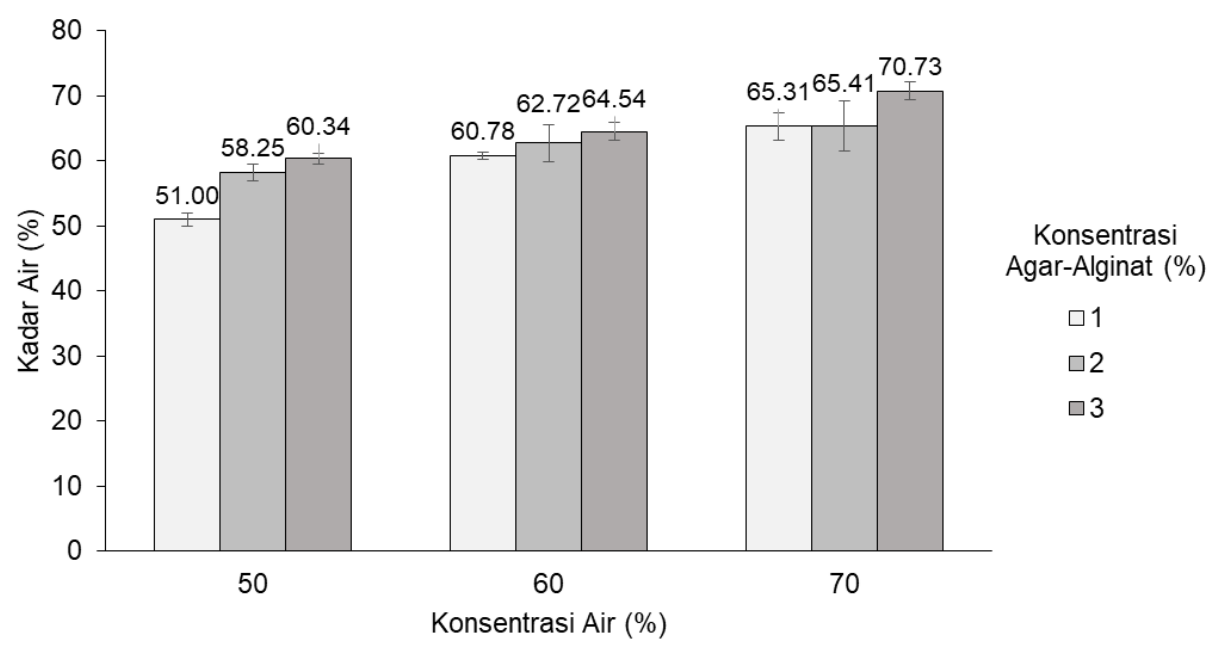

Gambar 3. Pengaruh variasi konsentrasi air dan agar-alginat terhadap kadar air sosis kerang hijau-tempe dengan proporsi $50 \%: 50 \%$

Hidrokoloid merupakan polimer yang bersifat hidrofilik yang membentuk sistem koloid dan membentuk gel pada suatu produk pangan (Saha and Bhattacharya, 2010). Hal tersebut yang menjadi penyebab dengan semakin banyaknya konsentrasi agar-alginat yang ditambahkan pada sosis akan berpengaruh terhadap peningkatan kadar air sosis. Beberapa jenis hidrokoloid sering ditambahkan pada pada produk sosis yang tidak hanya terbuat dari hasil peternakan, tetapi juga hasil perikanan (Prabpree and Pongsawatmanit, 2011).

\section{b. Tekstur}

Rerata nilai tekstur sosis dengan proporsi kerang hijau-tempe sebesar $50 \%: 50 \%$ dengan penambahan konsentrasi air dan agar-alginat yang berbeda-beda berada pada kisaran $0.16 \pm$ $0.01 \mathrm{~mm} / \mathrm{g} . \mathrm{s}$ hingga $0.29 \pm 0.01 \mathrm{~mm} / \mathrm{g}$.s. Hasil uji statistik menunjukkan bahwa perbedaan penambahan konsentrasi air yang diformulasikan dengan agar-alginat memiliki pengaruh yang nyata terhadap nilai teksturnya. Tekstur merupakan parameter yang menunjukkan karakteristik kekenyalan atau sifat kenyamanan mouthfeel. Hal ini sangat dipengaruhi oleh sifat gel yang terbentuk dikarenakan adanya penambahan hidrokoloid berupa agar-alginat. Gel yang memadat akan mempengaruhi elastisitas dan kekakuan dimana akan mempengaruhi nilai dari teksturnya.

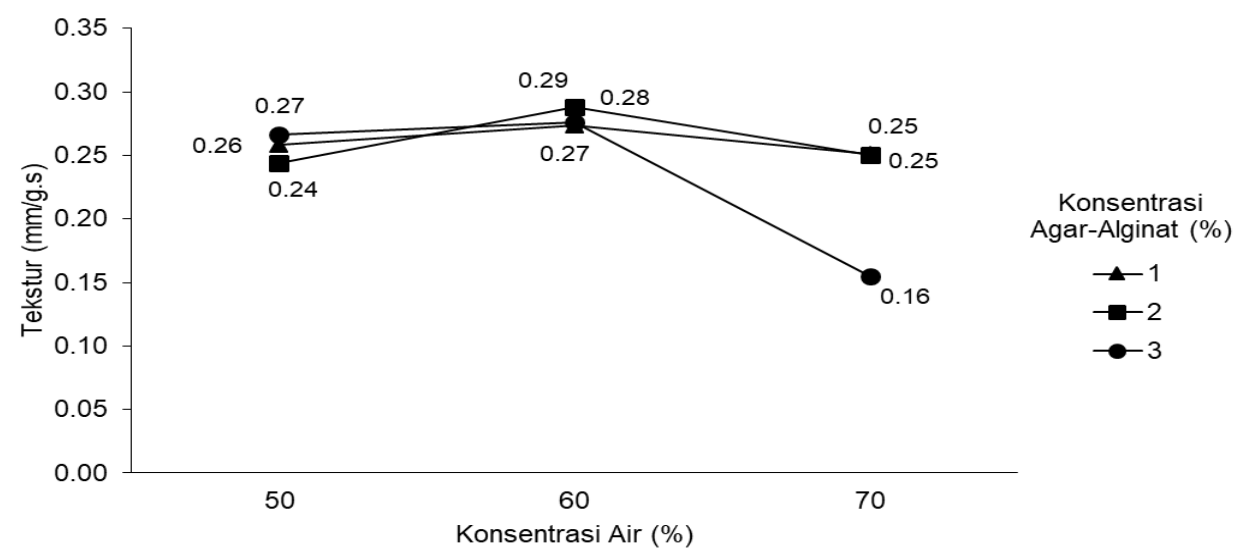

Gambar 4. Pengaruh variasi konsentrasi air dan agar-alginat terhadap tekstur sosis kerang hijau-tempe dengan proporsi $50 \%: 50 \%$ 
Pada Gambar 4 menunjukkan bahwa penambahan air dengan konsentrasi 60\% terjadi peningkatan, akan tetapi pada level $70 \%$ konsentrasi air yang ditambahkan membuat tekstur sosis semakin lembek atau mudah hancur. Nilai tersebut ini berbanding terbalik dari kadar airnya. Hal tersebut disebabkan karena tingginya penambahan air tidak diimbangi dengan konsentrasi binding agent dari agar-alginat, sehingga menyebabkan turunnya nilai tekstur. Penambahan air pada formulasi sosis yang semakin banyak akan menyebabkan kadar airnya meningkat serta mengakibatkan tekstur yang semakin lembek (Khotimah dan Hartatie, 2013).

\section{c. Water Holding Capacity}

Rerata nilai WHC sosis yang dihasilkan memiliki kisaran antara $11.29 \pm 1.01 \%$ hingga $19.07 \pm 0.58 \%$. Hasil analisis ragam perlakuan penambahan konsentrasi air dan agar-alginat memiliki pengaruh yang sangat signifikan terhadap nilai WHC. Nilai ini merupakan karakteristik suatu produk yang berhubungan dengan kemampuannya untuk menahan air yang di dalam produk. Parameter ini berkaitan dengan kadar air sosis, yakni semakin tinggi kadar air suatu produk, maka semakin tinggi juga nilai WHC dari produk tersebut.

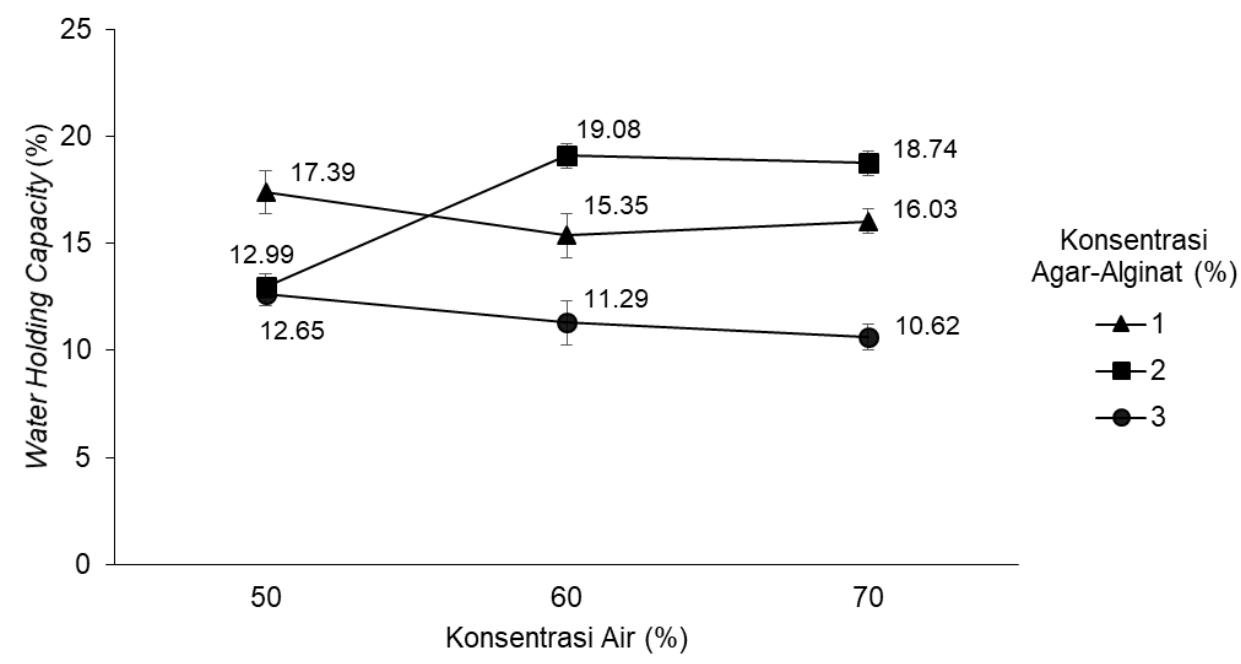

Gambar 5. Pengaruh variasi konsentrasi air dan agar-alginat terhadap WHC sosis kerang hijautempe dengan proporsi $50 \%: 50 \%$

Karakteristik dari hidrokoloid yaitu kemampuannya untuk pengikatan air yang berujung pada pembentukan gel. Karakter gel yang terbentuk tentunya dipengaruhi oleh gugus fungsional yang terdapat pada hidrokoloid. Sinergitas antara gugus fungsional hidrokoloid dengan komponen bahan lain akan mempengaruhi sifat gel yang terbentuk, sehingga akan mempengaruhi tekstur yang terbentuk (Herawaty, 2018). Hal tersebut secara tidak langsung akan mempengaruhi nilai WHC dari produk pangan. Hasil penelitian menunjukkan bahwa nilai WHC paling tinggi didapatkan pada sosis dengan penambahan konsentrasi air sebesar $60 \%$ dan konsentrasi agar-alginat sebesar $2 \%$. Hal ini diduga karena ketepatan konsentrasi antara air dan hidrokoloid yang saling berikatan menghasilkan nilai WHC yang terbaik.

\section{d. Stabilitas Emulsi}

Stabilitas emulsi merupakan sifat stabilnya suatu sistem emulsi dari produk pangan. Stabilitas emulsi dapat dilihat dari keseragaman molekul fase pendispersi dan fase terdispersi dalam kondisi baik. Hal tersebut dapat terjadi apabila suatu partikel terdispersi yang terdapat dalam produk pangan tidak mempunyai kecenderungan membentuk lapisan yang terpisah. Hasil 
pengamatan menunjukkan bahwa stabilitas emulsi dari sosis ini berkisar antara $90.91 \pm 0.28 \%$ hingga $95.79 \pm 0.35 \%$. Hasil analisis statistik menunjukkan bahwa penambahan konsentrasi air dan hidrokoloid berupa agar-alginat memiliki pengaruh yang nyata terhadap nilai stabilitas emulsi dari produk sosis ini. Hal tersebut menunjukkan bahwa adanya perlakuan tersebut dapat memperbaiki stabilitas emulsi dari sosis. Hidrokoloid berpotensi untuk dimanfaatkan sebagai emulsifier (Wulandari dkk., 2019). Selain itu, hidrokoloid merupakan golongan karbohidrat yang bersifat sebagai stabilizer yang dapat diartikan membuat sistem emulsi menjadi lebih stabil.

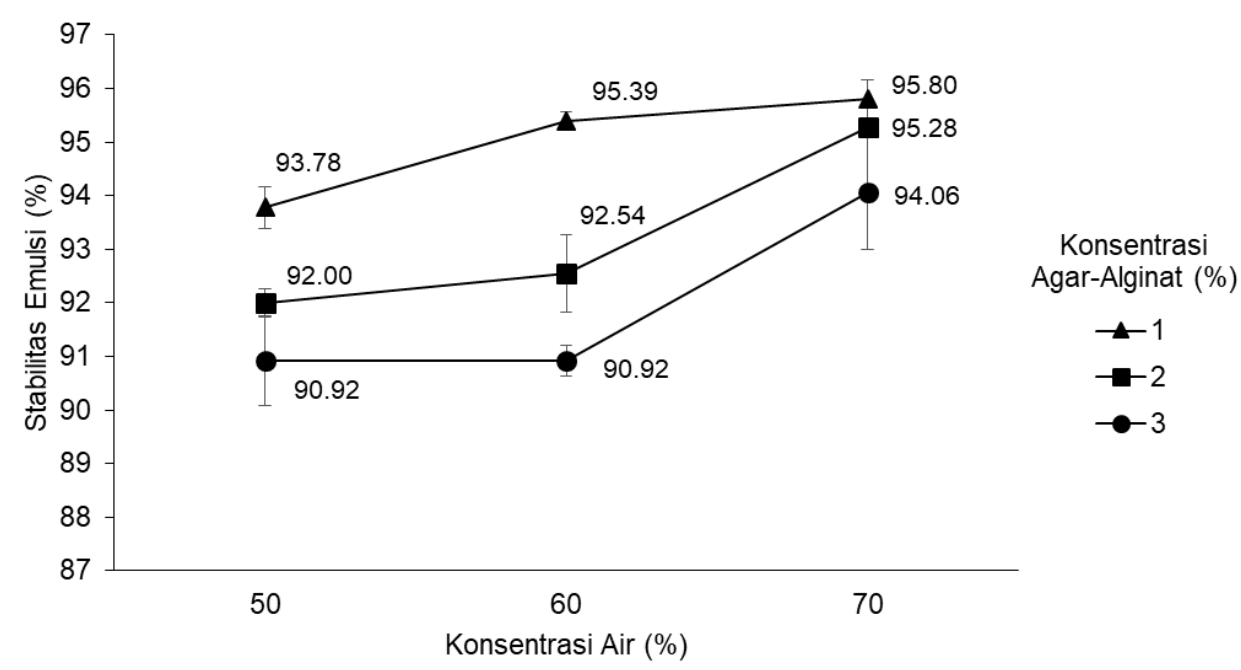

Gambar 5. Pengaruh variasi konsentrasi air dan agar-alginat terhadap stabilitas emulsi sosis kerang hijau-tempe dengan proporsi 50\%: 50\%

\section{SIMPULAN}

Hasil penelitian ini menunjukkan bahwa proporsi antara kerang hijau dan tepung tempe dengan perbandingan 50\%:50\% memiliki karakteristik organoleptik terbaik, sehingga formulasi ini difokuskan lebih lanjut untuk diperbaiki sifat fisik sosis. Selain sifat sensoris, juga dilakukan pengamatan terhadap pengamatan warna dengan melihat $L^{*}$, $a^{*}$, dan $b^{*}$ agar parameter penampakannya terukur secara objektif pada penentuan proporsi kerang hijau dan tepung tempe. Tahap penentuan dari penambahan konsentrasi air dan konsentrasi agar-alginat diperoleh bahwa sebanyak $60 \%$ air yang ditambahkan dengan konsentrasi agar-alginat sebesar $2 \%$ menghasilkan sosis dengan karakteristik fisik yang paling baik. Pada tahapan ini menunjukkan bahwa penambahan konsentrasi air dan hidrokoloid berpengaruh nyata terhadap parameter kadar air, tekstur, WHC, dan stabilitas emulsi.

\section{UCAPAN TERIMA KASIH}

Penelitian ini sepenuhnya didanai oleh LPPM - UPN “Veteran” Jawa Timur dalam Program Penelitian Mandiri dengan skema Riset Dasar (RISDA) untuk tahun 2019. Pelaksanaan penelitian ini juga dibantu oleh Lenna Fatmasari Qisthina sebagai teknisi.

\section{DAFTAR PUSTAKA}

Abdolghafour, B. and Saghir, A. 2014. Development in Sausages Production and Pratices-A Review. Journal of Meat Science and Technology. 2:3, 40-50 
Andrès, S., Zaritzky, N., and Califano, A. 2006. The Effect of Whey Protein Concentrates and Hydrocolloids on Texture and Colour Characteristics of Chicken Sausages. International Journal of Food Science and Technology. 41:8, 954-961

Beriain, M., Gómez, I., Petri, E., Insausti, K., and Sarriés, M. 2011. The Effects of Olive Oil Emulsified Alginate on the Physicochemical, Sensory, Microbial, and Fatty Acid Profiles of Low-Salt, Inulin-Enriched Sausages. Meat Science 88:1, 189-197

Chakraborty, K., Chakkalakal, S.J., Joseph, D., Asokan, P.K., and Vijayan, K.K. 2016. Nutritional and Antioxidative Attributes of Green Mussel (Perna viridis L.) from the Southwestern Coast of India. Journal of Aquatic Food Product Technology. 25:7, 968-985

Chin, K.B., Lee, H.L., and Chun, S.S. 2004. Product Characteristics of Comminuted Sausages as Affected by Various Fat and Moisture Combinations. Asian Australasian Journal of Animal Science 17:4, 538-542

Herawati, H. 2018. Potensi Hidrokoloid sebagai Bahan Tambahan Pada Produk Pangan dan Nonpangan Bermutu. Jurnal Litbang Pertanian. 37:1, 17-25

lqbal, M., Supriadi, A., dan Nopianti, R. 2015. Karakteristik Fisiko-Kimia dan Sensoris Sosis Ikan Gabus dengan Kombinasu Jamur Tiram (Pleorotus sp.). Jurnal Teknologi Hasil Perikanan. $4: 2,170-178$

Kementerian Kelautan dan Perikanan. 2015. Target Produksi Kerang Sudah Tercapai 50\%. Tanggal akses 12/12/2019

Khotimah, K. dan Hartatie, E.S. 2013. Kualitas Fisika Kimia Sosis Ayam dengan Penggunaan Labu Merah (Curcurbita moschata) sebagai Alternatif Pengganti Pewarna dan Antioksidan. Jurnal IImu Ternak. 13:1, 35-38

Leon, K., Mery, D., Pedreschi, F., and Leon, J. 2006. Color Measurement in L*a*b* Units from RGB Digital Images. Food Research International 39:10, 1084-1091

Mohan, A. 2014. Basics of Sausage Making: Formulation, Processing and Safety. UGA Extension Bulletin 1473. https://secure.caes.uga.edu/extension/publications/files/pdf/B\%201437_1. PDF. Tanggal akses 14/10/2019

Nalendrya, I., Ilmi, I.M.B., dan Arini, F.A. 2016. Sosis Ikan Kembung (Rastrelliger kanagurta L.) sebagai Pangan Omega 3. Jurnal Aplikasi Teknologi Pangan. 5:3, 71-75

Nisa, A.K. dan Wardani, A.K. 2016. Pengaruh Lama Pengasapan dan Lama Fermentasi Terhadap Sosis Fermentasi Ikan Lele (Clarias gariepinus). Jurnal Pangan dan Agroindustri. 4:1, 367-376

Prabpree, R. and Pongsawatmanit, R. 2011. Effect of Tapioca Starch Concentration on Quality and Freezethaw Stability of Fish Sausage. Kasetsart Journal - Natural Science. 45:2, 314-324

Saha, D. and Bhattacharya, S. 2010. Hydrocolloids as Thickening and Gelling Agents in Food : A Critical Review. Food Science and Technology. 47:6, 587-597

Sidu, S., Engelen, A. dan Hasan, A.A. 2018. Sosis Ikan Cakalang (Katsuwonus pelanis L.) dengan Penambahan Wortel (Daucus carota) dan Pati Sagu (Metroxylon sp). Journal of Agritech Science. 2:2, 117-129

Sundari, D., Almasyhuri, dan Lamid, A. 2015. Pengaruh Proses Pemasakan terhadap Komposisi Zat Gizi Bahan Pangan Sumber Protein. Media Litbangkes. 24:4, 235-242

Wulandari, R., Indriana, D., dan Amalia, A.N. 2019. Kajian Penggunaan Hidrokoloid sebagai Emulsifier pada Proses Pengolahan Cokelat. Jurnal Industri Hasil Perkebunan. 14:1, 2840 